\title{
Signals to their parliaments? Governments' use of votes and policy statements in the EU Council
}

\author{
Sara Hagemann, Stefanie Bailer and Alexander Herzog
}

\section{Introduction}

Do national parliaments play a role when governments negotiate in international politics? The power shift towards international organisations such as the European Union is usually seen to result in a loss of power for national parliaments. Yet, this paper shows how governments take into account their domestic political audiences and send signals to their national parliaments when negotiating at the international level. More specifically, we show that governments use votes and formal decision records in international law-making in order to signal to domestic audiences that they have pursued a particular policy outcome. This signalling is more pronounced when parliaments have strong scrutiny powers and if the government is in a weak position in domestic politics. As a number of countries experience considerable stress tests of the checksand-balances in place on their executives, the question of effective parliamentary oversight over government behaviour is of immense importance to the institutional design of national political systems. To this effect, we look at a case which is particularly informative and topical at the moment: the link between national parliaments and governments' behaviour in the Council of the European Union (the Council), where ministers from the 28 member states negotiate and adopt European Union (EU) policies. 
Our analysis comes at a time where the EU considers new mandates and initiatives to address key economic, financial, social and even humanitarian challenges in Europe. In addition, a number of national parliaments have recently concluded investigations into how the EU institutions can be held more accountable for their policy activities, and have sought to find ways for national parliaments themselves to play a more active role in EU politics. Opinion polls and national parties increasingly voice concern about a missing link between domestic preferences and EU level activity, a trend which has intensified since the offset of the Eurozone crisis (De Vries, 2018; Hobolt, 2016). We seek to contribute to this debate by exploring the relationship between political interests at the domestic level and governments' legislative behaviour at the EU level. More specifically, we investigate the extent to which governments take into account their national parliaments when deciding on policies in the EU Council. EU governments have seen a reaction from national parliaments to increasing Europeanization and politicisation of EU affairs, and a large number of parliaments have stepped up their efforts regarding oversight of their executives at the EU level (Rauh and De Wilde, 2018; Winzen, 2012). This happens both through parliamentary debates and in committee scrutiny of EU policies (Rauh and De Wilde, 2018; Winzen, et al., 2018). Hence, by now it is clear that members of the legislature have an incentive and are able to challenge their governments based on their political standpoint on EU matters. Hence, we can expect governments to foresee such challenges in the domestic arena and act accordingly at the EU level. Our measure for establishing the link between legislatures at home and executives' behaviour at the EU level is to explore whether governments take into account domestic audiences when recording policy positions in the Council's decision records: We look at whether scrutiny by national parliaments and the governments' standing in domestic 
politics have an influence on the votes and policy statements recorded in the Council's documents.

Our findings are based on an original dataset covering all legislative decisions negotiated in the Council since the enlargement to Eastern and Central Europe in 2004. Our analysis focuses on the voting behaviour of the Council members, as well as their use of formally recorded policy statements. These statements take the form of a short text which the governments can include in decision records to clarify their policy position in connection with a vote. Taking into account both the voting behaviour and the formally recorded policy statements, our empirical analysis is the most extensive investigation into formal legislative behaviour in the Council of $25+$ member states to date. As such these data are a valuable addition to negotiation research which is generally lacking data on often secretive international negotiations. For the first time we can investigate written statements in combination with the voting data from the most important legislative body of the European Union.

The paper proceeds as follows: The next section discusses recent findings in the political science literature on voting and strategic signalling in international political systems. We connect this literature with the political and institutional context for the governments' negotiations in the EU Council. In particular, we explain how an increase in the use of votes and formal records affects decision-making between the governments and has consequences for how individual governments position themselves. If government representatives know that domestic actors, including their national parliaments, are able to scrutinise their actions, they will consider how these records are perceived not only by European negotiation partners, but also in the domestic political sphere. Previous studies have established that the institutional capacity of parliaments 
to monitor the government in EU negotiations (Rauh and De Wilde, 2018; Winzen, et al., 2018). Hence, we assume that governments position themselves strategically in votes and formal policy statements in the EU Council in order to send signals to their national parliaments. We also argue that there is an increasing effect, such that the more formal oversight powers national parliaments have, the more likely governments are to use votes and formal decision records in the EU Council to send signals to their domestic political audiences. Last, we suggest that in addition to the effect of national parliaments' formal institutional powers, also the governments' standing in domestic politics is of importance: The more political pressure on a government in domestic politics, the more likely it is to use votes and formal statements in the EU Council to send signals to their national audiences. Thus, we add to previous findings on the domestic level in the two level games literature and outline how the varying institutional strength of the domestic actor and situation of the negotiating government impact the signalling dynamic. [I agree with what is said here, but the mention of two-level games etc is bit out of the blue and we don't include references. Either we should explain or leave it out?]

In the fourth section we provide details regarding the research design and present our results. The final section concludes with a perspective on the implications for the on-going political debates on national parliamentary oversight of governments' policy negotiations at the EU and international level.

\section{Signals and Voting in the EU Council}

We expect governments to engage in policy-making at the international level when it benefits them domestically (Keohane, 1984). Ambitions at the international level are shaped by the pay- 
off for the representatives and the interests they are there to represent, either directly or indirectly. 'Benefits' to domestic constituencies can be either in the form of furthering interests - i.e. welfare or a good - or it may be in the form of protecting a status quo from external intervention. Such incentives can be characterised as 'policy-driven' motivations. Governments' own motivations - their 'office-driven' ambitions - may relate to benefits they can achieve in the international setting, or the pay-off they receive at home from a position they take internationally. Hence, the international relations literature often engages with decision-making in international fora as cases of 'signalling games' (Fearon, 1997), where actors seek to communicate to other states or to domestic audiences (Kertzer and Brutger, 2016) in order to gain in 'policy'- or 'office' terms from this two-levelled game (Putnam, 1988).

An important domestic actor to take into consideration in this signalling game is a government's parliament. So far the influence of national parliaments on foreign policy has received little attention (Hill, 2003) as both parliaments and voters are assumed to prioritise domestic affairs over foreign policy (Uscinski, et al., 2009). However, there is growing evidence that the influence of national parliaments on foreign policy and international negotiations has become stronger (Howell and Pevehouse, 2005; Kaarbo and Kenealy, 2016; Kesgin and Kaarbo, 2010; Martin, 2005). If so, this should be particularly pronounced in the EU Council which deals with highly integrated policies that strongly impact citizens' lives at the domestic level. In fact, a growing literature on parliamentary oversight in the EU (Auel and Höing, 2014; Winzen, 2017) has shown that the institutional power of national parliaments has increased in the last decades and varies between countries (Winzen, 2013). Moreover, stronger institutional power to monitor the activities of the government motivates more debate in the national plenary (Winzen, et al., 
2018) as a reaction to increasing Europeanization and when opposition parties see a chance to criticize the government (e.g. during EU summits) (Rauh and De Wilde, 2018). Both the institutional capacity for monitoring as well as the political situation inside parliament are thus factors which we can assume to influence governments' strategies and policy positions at the EU level. Adding to previous work on the Council (Bailer, et al., 2015), we therefore argue that governments cater to stakeholders at the EU and national levels and that these are not only business actors or interest groups, but also include their national parliaments. In other words, our expectation is that EU governments take into consideration and behave according to their standing vis-à-vis their parliaments and the parties represented within them. We expect this dynamic between the parliaments and the governments to be shaped by two elements: 1) the formal, institutional constraints imposed on governments by national parliaments; 2 ) the political standing of governments vis-à-vis other parties in the domestic arena. For example, if a government has a comfortable majority in parliament and is doing well in opinion polls, government representatives have more leeway and will be less concerned about signalling games to domestic audiences (Palmer, et al., 2004). Conversely, governments who are under pressure at home will have more incentives to project themselves to their domestic audiences as competent leaders abroad. These two additional aspects increase our understanding of how "parliaments matter" in the international political setting.

Our idea that governments can use the political and legislative setting of the EU Council to their advantage in domestic politics has so far not been considered in any detail in the EU political science literature. In fact, many studies of EU Council decision-making focus on the interstate bargaining that take place between the members and approach the institution as a case of 
international diplomacy where governments negotiate through informal processes in 'corridor bargaining' and closed-door meetings (Hayes-Renshaw and Wallace, 2006; Kleine, 2013). Yet, a number of significant changes have been introduced to the procedures of Council meetings since 1999, when decisions were first implemented to formally organise and publicly record legislative activities in the Council. Today, Council meetings follow detailed procedural rules, in particular when the Council meets in a legislative capacity (General Secretariat of the Council of the EU 2009). Hence, while closed-door bargaining is still a reality in the preparation of policy proposals, government representatives must now formally record their positions when finally adopting legislative acts. Information is also made publicly available regarding the agendas, attendance and final conclusions from deliberations in all Council configurations (see www.consilium.europa.eu and www.votewatch.eu). Quantitative analyses of voting records and decision records from the Council are therefore now both possible and relevant, as attested by the burgeoning literature.

Thus, a number of important findings based on quantitative voting analyses has contributed to our understanding of what drives governments' behaviour in the Council: Bailer, Mattila and Schneider (2015) find that the presence of strong economic domestic interests dictate when a government decided to vote 'No' or 'Abstain' in the Council (see also Mühlböck and Tosun (2017)). Public opinion - in particular the public's attitude towards EU integration - has also been shown to have an effect in a number of core policy areas (Hagemann, et al., 2017). Others have found that a North-South or a North-South-East divide exists (Mattila, 2009), and that at times a left-right cleavage can also be detected (Hagemann and Hoyland, 2008; Mattila, 2004). Domestic adjustment costs to legislation (Arregui and Thomson, 2014) or negotiation 
dynamics (Smeets, 2015) such as support by other member states (Fantini and Staal, 2017) also play a role.

Nevertheless, it is safe to say that despite these important analyses the literature is still inconclusive and at times even conflicting concerning the motivators of government behaviour (Author 2). The only consensus so far appears to be that voting behaviour and coalition formation in the Council is an expression of a series of repeated games where patterns do appear, but where no permanent, stable positions are consistently confirmed over time and across all policy domains. In addition, it stands out that most existing studies do not consider any domestic political actors other than governments and voters ${ }^{1}$. The most notable exceptions are the studies by Finke (2017) and Stasavage (2004)who find that governments do not vote 'sincerely' in the EU Council, but rather seek to build reputations through their signals to domestic stakeholders ${ }^{2}$. We follow this same logic when we suggest that governments have an incentive to consider how their legislative records can be used in a broader context, rather than just relating to the policy positions they wish to convey to negotiation partners at the EU level.

\footnotetext{
${ }^{1}$ Although do see Auel, K. and Höing, O. (2014) 'Parliaments in the Euro Crisis: Can the Losers of Integration Still Fight Back?'. JCMS: Journal of Common Market Studies, Vol. 52, No. 6, pp. 118493, Auel, K., Rozenberg, O. and Tacea, A. (2015) 'To Scrutinise or Not to Scrutinise? Explaining Variation in EU-Related Activities in National Parliaments'. West European Politics, Vol. 38, No. 2, pp. 282-304, Puntscher Riekmann, S. and Wydra, D. (2013) 'Representation in the European State of Emergency: Parliaments against Governments?'. Journal of European Integration, Vol. 35, No. 5, pp. 565-82. for recent qualitative work which considers national parliaments in Eurocrisis negotiations. ${ }^{\mathrm{s}}$

${ }^{2}$ See also Schneider, et al., 2010 although they do not focus on voting in the Council.
} 
The mechanisms of our argument are as follows: When governments choose a negotiation positions in the EU Council, they have a strong incentive to follow the majority since there are few benefits involved when voting 'no' or 'abstain' against a carefully crafted majority proposal. Indeed, as legislation is set to go through in any case if a sufficient majority are supportive, opposition comes with the cost as the government will find itself excluded from any influence on the final text of a proposal, as well as possible repercussions for its negotiation 'goodwill' from other governments in future policy-making. Of course, if a policy is in direct contradiction and of some importance to a government's interests, others will find it understandable that even strong opposition is voiced at the negotiation table and in the final votes. However, governments are generally expected to adopt a 'spirit of collaboration' and only oppose as and when necessary; otherwise they risk being isolated and viewed as obstructive by their negotiation partners (Naurin and Wallace, 2008; Novak, 2013). The only reward governments may expect from an opposing position in the Council is hence the clear and strong signal that such opposition sends to their respective audiences both inside and externally to the Council setting. Therefore, we assume in accordance with other recent studies (see author, (Toshkov, 2017) that recorded opposition in the Council is not necessarily intended to stop the decision-making process as in most cases this will not be possible by a single- or small number of governments at the final decision stages. Rather, the Council's decision records are seen as a tool through which governments strategically choses to signal to external stakeholders that they have taken a particular political stand in the EU setting. As the national parliaments are a central national stakeholder we expect that governments position themselves in votes and formal policy statements in the EU Council in order to direct such signals to their parliaments. We suggest this 
to have an increasing effect such that the signalling will be particularly pronounced when governments know that their recorded positions are picked up at home: national parliaments with extensive scrutiny powers are more actively engaged in policy oversight of their governments' actions in EU affairs, than parliaments who have fewer powers (Rauh and De Wilde, 2018; Winzen, et al., 2018). Increased oversight and control mechanisms in the national parliament should therefore motivate governments to signal more to these domestic actors. Hence, we propose that

Hypothesis 1) the more formal powers national parliaments have, the more likely their governments are to use votes and formal decision records in the EU Council to send signals to their domestic political audiences.

In addition to the formal, institutional constraints imposed on the governments by their parliaments, it is likely that also the political standing of the government has an impact on its policy strategies in the international arena. Several domestic situations independent from parliamentary scrutiny procedures may motivate governments to react to actors in parliament more than they usually do in international negotiations (Cowhey, 1993). For example, when power is particularly dispersed in parliament, e.g. due to a high number of parties (Laakso and Taagepera, 1979; Nyblade and O'Mahony, 2011) or if the government is in a vulnerable position as a minority government (Clare, 2010; Laver and Schofield, 1998; Oktay, 2014), it could be expected that they more frequently show that they are responsive to their parliaments through the communication of political signals from the EU level. Last, governments may also increase this signalling game when they are under closer scrutiny during election time than any other time 
in the electoral cycle (Blais and Nadeau, 1992; Rauh and De Wilde, 2018). We elaborate on each of these dynamics below. In sum, our second hypothesis is that:

Hypothesis 2: The more political pressure on a government from its national parliament, the more likely it is to use votes and formal statements in the EU Council to send signals to their domestic audiences.

A last step in our analysis is to further dissect the governments' behaviour by comparing the votes with the signals that are transmitted through formal policy statements. As this project is the first elaborate study of the policy statements (cf. Author), we have no firm evidence whether formal statements are made following the same logic as voting ${ }^{3}$. Our assumption is that both votes and policy statements come in different categories and can be ordered hierarchically in terms of their severity: A 'No' vote in the Council is costly as the legislation is set to be passed in any case and voting 'No' sets the government apart from the majority's agreement; an 'Abstention' is less costly than a 'No' vote but is still unpopular with negotiation partners as it works against the formation of the required majority; 'Yes' votes come only with pay-offs in the negotiation process as support for a majority position ensures influence on the final consensus agreement. For the

3 See also e.g. Lewis, J. (2008) 'Strategic bargaining, norms and deliberation'. Unveiling the Council of the European Union Springer). and Novak, S. (2013) 'The Silence of Ministers: Consensus and Blame Avoidance in the Council of the European Union'. JCMS: Journal of Common Market Studies, Vol. 51, No. 6, pp. 1091-107.for discussions of the implications associated with votes and statements. 
formal statements, we assume that there are no costs associated with submitting such statements as they do not obstruct or benefit the passing of legislation. But having looked into the content of the policy statements (more below) we see that these also vary in terms of their positions vis-à-vis a majority agreement: Some appear as merely clarifications of a government's reasons for supporting a vote; others clearly demonstrate concern with either part or the whole proposal being voted on; and still others include outright disagreement with the act. They therefore appear to include additional and valuable information regarding the governments' policy positions, and we investigate whether they follow or differ from the governments' voting patterns.

\section{Data and Descriptive Analysis}

Our empirical investigation relies on an original data set that covers all legislative decisions adopted in the Council since the enlargement to Central- and Eastern Europe in May 2004 until the end of 2016. In the statistics presented below we analyse the governments' decisions to vote 'Yes', 'No' or 'Abstentions' in Council decision-making, as well as the use of formal policy statements in conjunction with these votes. In total, this provides us with 1,722 Council acts covering 45,869 country-vote observations for the twelve-year period.

Our data confirm that formally recorded opposition in the Council remain a rare event, as highlighted in previous studies and discussed above: during the years 2004-2016 only in 219 $(12.72 \%)$ cases out of our 1,722 legislative acts did one or more countries vote against the majority. Adding 'abstentions' as a form of opposition - as abstaining countries count against the mobilisation of a majority - the level of recorded opposition rises to $404(23.46 \%)$ cases. In 
comparison, formal policy statements are used more frequently: In 463 (26.89\%) out of the 1,722 acts, at least one formal statement was submitted by a country.

Looking further into this distribution, Table 1 below shows the recording of votes and formal statements across the 45,869 country-vote observations. In total, the governments have submitted 1,420 formal statements. Most of these statements (77\%) are recorded when a country voted in favour of a decision, which is a result of the fact that most votes are 'yes' votes. The remaining statements are about equally divided between opposing votes and abstentions, with 163 and 168 statements, respectively. Yet, looking at the differences in the proportions of formal statements across vote categories, we find that a country is substantially more likely to submit a formal statement if it has voted against or abstained. While in only about $2.5 \%$ of 'yes' votes a country also submitted a statement, those proportions increase to $31 \%$ when a country voted 'no', and to $35 \%$ if a country abstained. In other words, in about one out of three cases in which a country votes against the majority or abstains, it also submits a formal statement. The higher rate of statements in conjunction with opposing votes may be a first indication that the formally recorded statements are used to state or justify a country's decision to oppose the majority - and we would like to know what drives this behaviour.

Table 1 in here

To further investigate the purpose of the formal statements vis-à-vis the votes, we have coded the types of formal statements submitted by the governments. Our variable "Type of Statement" captures both whether or not a statement was made ( $0=$ No statement) and the sentiment of the 
statement (1=neutral, 2=positive, 3=concerned, 4=negative). From the 864 formal statements made by the EU governments in the period from $2004-2014,28 \%$ were coded as neutral, only $5.8 \%$ as positive, while $31.7 \%$ were concerned and $34.3 \%$ in a negative form. Examples of positive, concerned and negative statements can be found in Table B1 in the web appendix.

Looking at the use of formal statements in combination with the rejection of a proposal ('abstention' and 'no' vote), we find that formal statements are not only used more often when governments agree with a proposal, but that they actually seem to be a weaker form of opposition since 'concerned' and 'negative' statements are most often used when agreeing with a proposal. Indeed, it appears as if governments use the statements to put on the record that they are either in direct disagreement or partly disagree/are concerned about a policy, but do not want to make a more pronounced rejection by voting against or abstaining from the vote. As per our hypotheses above, we assume these positions are used to signal to domestic political audiences that the governments have taken a stand in the EU Council setting. We therefore organise our data for a regression analysis of both the votes and of the formal statements to investigate the drivers behind this behaviour:

\section{Variables}

Our first dependent variable is a dummy variable, 'Abstain or vote against', coded 1 if a country voted 'no' or 'abstained', and 0 if it voted 'yes'. Our second dependent variable is ordinal to capture 'Increasing Opposition', which combines the votes and statements in order of hierarchy. This variable consists of twelve categories which range from complete support (a 'yes' vote without a formal, coded as 0 ) to the strongest form of opposition (a 'no' vote submitted in 
combination with a formal statement of outright disagreement with the proposal, coded as 11). Details of the coding can be found in Table B2 in section B in the web appendix.

The independent variables for our analysis are all obtained from external sources (described below). Unfortunately, some of these variables do not cover the time after December 2014 as data is not yet available. Therefore, we have had to make some adjustments to the Council data and confine our regression models to the years from 2004-2014. This still leaves us with 1,513 decisions on Council proposals in which 'yes' votes, 'no' votes, and 'abstentions' were recorded by the governments. The result is a total of 27,737 observations for the member states' voting behaviour, and 872 recorded policy statements.

Our main independent variables capture the national parliamentary factors discussed above. The first of these is provided by Winzen (2012), who has developed an encompassing cross-national and longitudinal measure of national parliamentary powers concerning EU legislation. We make use of this thorough instrument to investigate whether governments' positions at the EU level is influenced by these national parliamentary powers. Figure A5 in Section A in the web appendix shows the distribution of the parliamentary power index across countries.

Our second independent variable captures the distribution of bargaining power between parties in national parliaments, referred to as the 'bargaining power fragmentation index' (Anderson, et al., 2014). This index is similar to previous measures of the effective number of parties (Laakso and Taagepera, 1979) but considers not only parties' relative weights in parliament, but also their bargaining power by including majority voting requirements (Caulier \& Dumont 2005; Nyblade \& O'Mahony 2011). The number of parties in parliament, and the 
bargaining power distribution between these parties, is a frequently used measure for the legislative fragmentation within legislatures, and can be used for indications of divergence in opinions, level of conflict or stability. It also incorporates the idea that more than one opposition party can seek to criticize the government in the public plenary floor so that more opposition parties may mean more chances for criticism.

A third variable is included for each government's distance to the next national election (in number of days). This measure is inspired by the electoral budget cycle literature (Blais \& Nadeau 1992) and controls for the possibility that signalling to domestic audiences becomes more important as the next election approaches: governments may perceive a greater incentive to explain their behaviour and domestic stakeholders may pay greater attention to their governments' action in domestic as well as international fora when a general election is near (see author). While Rauh and de Wilde (2018) have found less debate about the EU during national election campaigns, we take this variable into account since our signalling game might be a more subtle game between government and parliament in comparison to taking up a plenary debate as in the cited study.

Last, we follow the important findings from previous studies and take into account the political positions of the populations in terms of their pro-/anti-EU attitudes, the left/right as well as the pro-/anti-EU position of the governments. From Bailer et al. (2015) we furthermore include two variables to establish the effect of economic domestic interests on the governments' legislative positions: GDP and whether the country is a net recipient or contributor to the EU budget. We assume that national parliaments may have a confounding effect on these economic 
interests and have hence included them in our model both as separate independent variables as well as controlled for interaction effects (cf. the web appendix).

We report our results below. Summary statistics of the dependent and independent variables is provided in Table B3 in the web appendix. ${ }^{4}$

\section{Results}

Table 2 presents the results from two models. Model 1 is a logistic regression model using the 'Abstain or vote against' dummy as dependent variable. Model 2 is a linear regression, using as dependent variable the 12-point 'Increasing Opposition' measure. ${ }^{5}$ As explained above, this more

${ }^{4}$ In Section $C$ in the web appendix, we provide the results of models that include additional control variables based on findings from previous work, including: the presence of minority governments, whether or not a government holds the EU presidency, and if there are strong economic interests in specific sectors (agriculture and the service sector). Since more than $80 \%$ of the governments in our dataset are in a coalition, we do not control for coalitions in our model. We have also estimated models that control for interactions between our key independent variables (parliamentary scrutiny and bargaining power) as well as between these two variables and the preference estimates (government left/right and pro/anti EU). None of these interactions had a significant coefficient. Finally, we re-estimated all models with fixed-effects for policy areas, which did not substantively change our results.

${ }^{5}$ The estimation of standard errors in both models considers that vote decisions are clustered by proposals. We have also estimated the models with document-level clustering of standard errors, which yielded almost identical results. 
fine-grained measure orders the different ways to voice consent and dissent in an order to get a more elaborate impression of the dynamics at play. ${ }^{6}$

Table 2 in here

As expected, the results show that an increase in parliamentary oversight increases a government's likelihood to reject a proposal. Figure 3 illustrates the magnitude of this effect: while the overall probably to reject is relatively small due to the rare nature of the event, all else equal, the probability to reject more than doubles when parliamentary oversight increases from its smallest observed value (parliamentary control in Luxembourg and Belgium) in the sample to the highest value (parliamentary control in Denmark). The data therefore appears to support our proposition that governments are more likely to take a stand and record their disagreement in the EU Council the more formal scrutiny powers their national parliaments have.

Figure 1 in here

Also the bargaining power fragmentation index has a positive and significant impact on the governments' likelihood to signal discontent in the Council. This is the case both for the votes (Model 1) and for the combined measure of votes and formal statements (Model 2). This confirms

\footnotetext{
6 We have also estimated an ordered logic model, which leads to substantially identical conclusions. For simplicity of interpretation, we here report the results from the linear regression model.
} 
our expectation that a higher level of national parliamentary contestation motivates governments to send signal to their domestic audiences. In fact, for Model 1 the probability to reject becomes three times higher from the lowest values of the bargaining power fragmentation to the highest (e.g. in Belgium).

Interestingly, the variable which measures the distance to next election does not come out as significant for either of the models. We had expected the elections to be of significance, but perhaps the effect is - if any exists - more limited and similar to the findings reported in Hagemann et al (2017): they find that governments are more likely to oppose the majority in the Council in response to public opinion only in areas which include decisions to further expand the EU's powers.

For the remaining variables, several findings already discussed in previous studies get confirmed: as for domestic political variables, both the governments' and the publics' support for the EU are significant, while also the governments' left-right political orientation have an impact on their behaviour in Model 2. In addition, the overall economic power of the countries (here measured with the ranking order of GDP) and their EU budget recipient status have the expected negative effect: less affluent countries and countries which benefit from the EU budget do not voice opposition in the Council as often as those with a higher GDP. Last, we find that the overall level of contestation of a proposal also contributes to the likelihood of a government rejecting a proposal. This might be because some proposals are simply more contested and thus lead to more opposition, although the effect of such opposition can be costly if the result is a failure for the proposal to meet the decision threshold. 
To further dissect these results, we now turn to a multinomial logit model for our three categories of statements: The 'neutral', 'positive' and 'negative' statements. ${ }^{7}$ Table 3 presents the results and shows that parliamentary oversight has a positive and statistically significant effect for submitting a statement - but only for the negative statements. There is no effect for neutral and positive statements, making it clear that these records are used less strategically visà-vis the national parliaments. ${ }^{8}$ The results also show that, in contrast to our results above, the closeness to next election does increase the likelihood of submitting a statement, but this is only the case for negative statements and not the others. Again, this could mean that the statements serve a purpose for the governments vis-à-vis domestic audiences, although here it appears as if this is only when they wish to record their disagreement. Nevertheless, in these cases the effect is rather strong: governments at the beginning of their term - with 4-5 years (max 1800 days) away from the next election - have the smallest probability to submit a negative statement (compared to submitting no statement), but this probability more than doubles for governments only days or weeks away from the next election (cf. Figure A7 in web appendix A).

Table 3 in here

The rest of our findings from Table 3 are as follows: The bargaining power fragmentation index does not come out as significant for any of the categories of statements, which means we can

\footnotetext{
${ }^{7}$ As above, details of the coding of the statements can be found in Section B of the web appendix.

${ }^{8}$ The magnitude of this effect is illustrated in Figure A6 in Section A of the web appendix.
} 
conclude this only has an effect for the governments' voting behaviour or the voting behaviour combined with the formal statements (Table 1), but not for the individual categories of formal statements taken in isolation. On the other hand, the governments' left-right political position plays a role for the negative statements, but not for other types, and this is also the case for the public's support for the EU and the country's position as a recipient or contributor to the EU budget. Therefore, these variables all follow the same patterns as the ones reported for the votes. Conversely, the variables which capture the governments' pro-/anti-EU stance only come out as significant for the positive statements. A country's GDP ranking has an effect on the neutral and the opposing statements, but not on the positive statements. Only the measure of the total number of oppositions on a proposal is significant for all three categories.

In sum, it appears as if the formal statements serve a distinct purpose for the governments and that it makes sense to think of them in terms of 'severity': Many of the variables which were significant for a governments' decision to oppose the majority in the votes appear to follow a same logic for 'opposing' statements, while the 'neutral' and 'positive' statements are much less driven by our external predictors. ${ }^{9}$

\section{Conclusion}

The literature on government behaviour in international organisations pays little attention to the role of national actors and institutions. While a number of influential studies have highlighted

\footnotetext{
9 This holds true for the 'political' and 'economic' variables included in our model as well as for the additional control variables highlighted in previous studies and reported in the web appendix.
} 
the two-levelled structure of international decision-making, no systematic evidence has been presented with regards to how the two levels - domestic and international - in fact impact on each other with regards to governments' policy positions and strategies.

This paper has argued that when acting at the international level, governments have incentives to appear as responsive to domestic audiences while looking to find solutions to the policy challenges on the table. In other words, they do not act in isolation from domestic institutions and political pressures but may in fact seek to cater to those actors from the international arena. Focusing on the European Union's primary legislative body, the Council of the European Union, our results demonstrate that governments indeed act strategically when considering how to position themselves on legislative proposals. The legislative decision records show that contest has increased in the Council over the past decades, while our analysis also makes it clear that decision-makers use the formal recording of their positions to send signals to external actors rather than solely convey policy preferences to fellow negotiators.

We shed light on the dynamics between the EU executives and legislatures by demonstrating that more formal powers of national parliaments lead to more recorded opposition to legislative proposals at the EU level. When a national parliament has extensive competences to scrutinise and amend government policies, governments are more likely to oppose the majority in the EU Council and record their positions in formal policy statements following the adoption of an act. This links previous findings on the reasons for EU debates in national parliaments (Rauh and De Wilde, 2018; Winzen, et al., 2018) back to the EU negotiation table and demonstrates that governments act pre-emptively to the power of the legislature for issuing formal statements. Government behaviour in the EU Council is also conditioned by the 
degree of fragmentation in the parliament, and to some degree to the proximity to national elections: Governments are more likely to publicly take a stand against the majority and record formal policy statements when they are constrained in their domestic political arena. and fear that parliamentarians blame them and raise attention to certain already agreed debates at the EU level.

However, we see a difference in the kinds of signals governments appear to send through the legislative records: Rejecting the majority in voting can be considered a 'strong' signal as there may be costs associated with being excluded from influencing the final text of a majority agreement. On the other hand, the recording of policy positions in formal statements do not come with such a cost but can still make it clear that a government has had substantial concerns or is in outright disagreement with a decision. We find that these statements are therefore less severe, but nevertheless a relevant signalling tool for the government representatives.

Our analysis stops short of establishing the extent to which this form of government responsiveness to parliamentary scrutiny is also noted by domestic actors, and in particular to what degree the national parliaments and their committees actually pay attention to the EU votes and decision records. However, several extensive and rigorous accounts exist with regards to these questions (Auel \& Höing 2015; Gattermann \& Hefftler 2015; Hoerner 2017). Based on their findings - that parliaments vary greatly in terms of both formal and actual scrutiny activities of their governments - we remain convinced that the scrutiny activities carried out by the national parliaments regarding the governments' activities in EU affairs can indeed explain our results above: Governments have incentives to cater to the national political actors in their parliaments as voting records and Council documents are an integrated part of scrutiny 
procedures in many domestic parliaments. In this way, our findings hence provide an important starting point for understanding the link between national parliaments and governments in the European Union by going beyond the received wisdom that EU negotiations are conducted behind closed doors. They point to an important connection between government ministers and national democracies in European affairs which has so far not been explored in the literature. This approach and our resulting findings may very well be relevant to other international contexts too: to what degree should we consider domestic institutional and political constraints as defining for the bargaining space governments operate within at the international level, and when should we expect governments to engage in 'signalling games' to domestic audiences in a supranational context? Our analysis indicates that domestic politics and institutions matter, and in particular that government representatives are responsive when parliamentary control increases over legislative policy decisions taken outside of the domestic sphere. 


\section{Bibliography}

Anderson, S., Bergman, T. and Ersson, S. (2014) The European Representative Democracy Data Archive, Release 3 (www.erdda.se: Riksbankens Jubileumsfond).

Arregui, J. and Thomson, R. (2014) 'Domestic adjustment costs, interdependence and dissent in the Council of the European Union'. European Journal of Political Research, Vol. 53, No. 4, pp. 692-708.

Auel, K. and Höing, O. (2014) 'Parliaments in the Euro Crisis: Can the Losers of Integration Still Fight Back?'. JCMS: Journal of Common Market Studies, Vol. 52, No. 6, pp. 1184-93.

Auel, K., Rozenberg, O. and Tacea, A. (2015) 'To Scrutinise or Not to Scrutinise? Explaining Variation in EU-Related Activities in National Parliaments'. West European Politics, Vol. 38, No. 2, pp. 282-304.

Bailer, S., Mattila, M. and Schneider, G. (2015) 'Money makes the EU go round: The objective foundations of conflict in the Council of Ministers'. JCMS: Journal of Common Market Studies, Vol. 53, No. 3, pp. 437-56.

Blais, A. and Nadeau, R. (1992) 'The electoral budget cycle'. Public Choice, Vol. 74, No. 4, pp. 389-403.

Clare, J. (2010) 'Ideological Fractionalization and the International Conflict Behavior of Parliamentary Democracies'. International Studies Quarterly, Vol. 54, No. 4, pp. 965-87.

Cowhey, P.F. (1993) 'Domestic Institutions and the Credibility of International Commitments: Japan and the United States'. International Organization, Vol. 47, No. 2, pp. 299-326.

De Vries, C. (2018) Euroscepticism and the Future of European Integration (Oxford: Oxford University Press).

Fantini, M. and Staal, K. (2017) 'Influence in the EU: Measuring Mutual Support'. JCMS: Journal of Common Market Studies, pp. n/a-n/a.

Fearon, J.D. (1997) 'Signaling foreign policy interests: Tying hands versus sinking costs'. Journal of Conflict Resolution, Vol. 41, No. 1, pp. 68-90.

Finke, D. (2017) 'Underneath the culture of consensus: Transparency, credible commitments and voting in the Council of Ministers'. European Union Politics, Vol. 18, No. 3, pp. 339-61.

Hagemann, S., Hobolt, S.B. and Wratil, C. (2017) 'Government responsiveness in the European Union: Evidence from Council voting'. Comparative Political Studies, Vol. 50, No. 6, pp. 850-76.

Hagemann, S. and Hoyland, B. (2008) 'Parties in the Council? '. Journal of European Public Policy, Vol. 15, No. 8, pp. 1205-21.

Hayes-Renshaw, F. and Wallace, H. (2006) The Council of Ministers (London: Palgrave Macmillan).

Heisenberg, D. (2005) 'The Institution of 'Consensus' in the European Union: Formal versus Informal Decision-making in the Council'. European Journal of Political Research, Vol. 44, pp. 65-90. 
Hill, C. (2003) The changing politics of foreign policyPalgrave).

Hobolt, S.B. (2016) 'The Brexit vote: a divided nation, a divided continent'. Journal of European Public Policy, Vol. 23, No. 9, pp. 1259-77.

Howell, W.G. and Pevehouse, J.C. (2005) 'Presidents, Congress, and the use of force'. International Organization, Vol. 59, No. 1, pp. 209-32.

Kaarbo, J. and Kenealy, D. (2016) 'No, prime minister: explaining the House of Commons' vote on intervention in Syria'. European Security, Vol. 25, No. 1, pp. 28-48.

Keohane, R.O. (1984) After Hegemony (Princeton: Princeton University Press).

Kertzer, J.D. and Brutger, R. (2016) 'Decomposing audience costs: Bringing the audience back into audience cost theory'. American Journal of Political Science, Vol. 60, No. 1, pp. 234-49.

Kesgin, B. and Kaarbo, J. (2010) 'When and How Parliaments Influence Foreign Policy: The Case of Turkey's Iraq Decision'. International Studies Perspectives, Vol. 11, No. 1, pp. $19-36$.

Kleine, M. (2013) Informal governance in the European Union: How governments make international organizations workCornell University Press).

Laakso, M. and Taagepera, R. (1979) 'The" Effective" Number of Parties:" A Measure with Application to West Europe"'. Comparative Political Studies, Vol. 12, No. 1, pp. 3.

Laver, M. and Schofield, N. (1998) Multiparty government: The politics of coalition in EuropeUniversity of Michigan Press).

Lewis, J. (2008) 'Strategic bargaining, norms and deliberation'. Unveiling the Council of the European Union Springer).

Martin, L.L. (2005) 'The president and international commitments: Treaties as signaling devices'. Presidential Studies Quarterly, Vol. 35, No. 3, pp. 440-65.

Mattila, M. (2004) 'Contested Decisions. Empirical Analysis of Voting in the EU Council of Ministers'. European Journal of Political Research, Vol. 43, No. 1, pp. 29-50.

Mattila, M. (2009) 'Roll Call Analysis of Voting in the European Union Council of Ministers after the 2004 Enlargement'. European Journal of Political Research, Vol. 48, No. 6, pp. 840-57.

Mühlböck, M. and Tosun, J. (2017) 'Responsiveness to Different National Interests: Voting Behaviour on Genetically Modified Organisms in the Council of the European Union'. JCMS: Journal of Common Market Studies, pp. n/a-n/a.

Naurin, D. and Wallace, H. (2008) 'Unveiling the Council of the European Union: Games governments play in Brussels'. (Houndmills Basingstoke: Palgrave Macmillan ).

Novak, S. (2013) 'The Silence of Ministers: Consensus and Blame Avoidance in the Council of the European Union'. JCMS: Journal of Common Market Studies, Vol. 51, No. 6, pp. 1091-107.

Nyblade, B. and O'Mahony, A. (2011) 'How Parties Count'.

Oktay, S. (2014) 'Constraining or enabling? The effects of government composition on international commitments'. Journal of European Public Policy, Vol. 21, No. 6, pp. 860-84.

Palmer, G., London, T. and Regan, P. (2004) 'What's stopping you?: The sources of political constraints on international conflict behavior in parliamentary democracies'. International Interactions, Vol. 30, No. 1, pp. 1-24. 
Puntscher Riekmann, S. and Wydra, D. (2013) 'Representation in the European State of Emergency: Parliaments against Governments?'. Journal of European Integration, Vol. 35, No. 5, pp. 565-82.

Putnam, R.D. (1988) 'Diplomacy and domestic politics: The logic of two-level games'. International Organization, Vol. 42, No. 3, pp. 427-60.

Rauh, C. and De Wilde, P. (2018) 'The opposition deficit in EU accountability: Evidence from over 20 years of plenary debate in four member states'. European Journal of Political Research, Vol. 57, No. 1, pp. 194-216.

Smeets, S. (2015) 'Unanimity and exposure in the EU Council of Ministers - or how the Dutch won and lost the ICTY debate'. European Journal of Political Research, Vol. 54 , No. 2, pp. 288-304.

Stasavage, D. (2004) 'Open-Door or Closed-Door? Transparency in Domestic and International Bargaining'. International Organization, Vol. 58, No. 4, pp. 667-703.

Toshkov, D.D. (2017) 'The impact of the Eastern enlargement on the decision-making capacity of the European Union'. Journal of European Public Policy, Vol. 24, No. 2, pp. 177-96.

Uscinski, J., Rocca, M.S., Sanchez, G.R. and Brenden, M. (2009) 'Congress and foreign policy: Congressional action on the Darfur genocide'. PS: political science \& politics, Vol. 42, No. 3, pp. 489-96.

Winzen, T. (2012) 'National Parliamentary Control of European Union Affairs: A Crossnational and Longitudinal Comparison'. West European Politics, Vol. 35, No. 3, pp. $657-72$.

Winzen, T. (2013) 'European integration and national parliamentary oversight institutions'. European Union Politics, Vol. 14, No. 2, pp. 297-323.

Winzen, T. (2017) Constitutional Preferences and Parliamentary Reform: Explaining National Parliaments' Adaptation to European Integration (Oxford: Oxford University Press).

Winzen, T., de Ruiter, R. and Rocabert, J. (2018) 'Is parliamentary attention to the EU strongest when it is needed the most? National parliaments and the selective debate of EU policies'. European Union Politics, Vol.

https://doi.org/10.1177/1465116518763281 pp. 1465116518763281. 